Available Online : https://proceeding.researchsynergypress.com/index.php/cset/index

RSF Conference Series: Engineering and Technology

ISSN 2809-6843(Online) | 2809-6878 (Print)

Volume 1 Number 1 (2021): 355-362

\title{
Mineral Preparation Using Rod Mill for Mineral Galena Characterization
}

\author{
Riria Zendy Mirahati1, Yasmina Amalia², Mochamad Juliyanto33, Lintang Larasati Adi Putri4 \\ 1) Metallurgical Engineering Study Program - Mining Engineering Department, Faculty of mineral \\ engineering, UPN “Veteran” Yogyakarta, Indonesia
}

\begin{abstract}
Abstact
Galena mineral preparation was carried out for mineral characterization. The mineral characterization carried out included XRD (X-Ray Diffraction), XRF (X-Ray Fluorescence), SEM-EDS (Scanning Electron Microscope-Energy Dispersive X-Ray). The preparation of galena minerals begins with the process of reducing the grain size including crushing and grinding. The results of crushing and grinding are then separated based on grain size using a sieve or siever to get a grain size of -200 mesh. The grinding process using a rod mill needs to be timed, so that the results are not too fine which is causing the recovery in the mineral concentration process to be low.
\end{abstract}

Keywords: Galena mineral, mineral preparation, crushing, grinding, grain size

\section{INTRODUCTION}

This is an open access article under the CC-BY-NC license

The stages of galena mineral processing include ore characterization, comminution, grain size grouping, and concentration. The comminution process includes crushing and grinding. The grouping of the grain size on a laboratory scale, better known by the term sieving. The concentration process can be carried out by several methods, namely hand sorting, heavy medium separation, concentration of gravity, magnetic and electromagnetic separators, and flotation. Selection methods used bases that make up the mineral composition of ore or ore as well as physical and chemical properties of minerals contained in the ore. Acquisition or recovery of minerals will produce the optimal value when done with proper mineral preparation before the concentration process is done. The activity is in the form of seed characterization, to find out what minerals make up the ore.

The ore obtained from the field is usually not directly in the form of a uniform grain size, but in the form of lumps. The lumps are then subjected to a comminution process, including the crushing and grinding processes. Crushing of lumps using a jaw crusher, while grinding using a rod mill. Results of crushing and grinding subsequent separation by grain size or sizing to obtain mineral grain size -200 mesh. A tool for separating minerals based on grain size using a sieve. After all the comminution and sizing processes are carried out, the ore characterization is carried out, in the form of XRD (X-Ray Diffraction), XRF (X-Ray Fluorescence), SEM-EDS (Scanning Electron Microscope-Energy Dispersive X-Ray). The results of the mineral characterization are then used as the basis for selecting the concentration method for galena mineral processing.

\section{METHODOLOGY}

The sample of galena that has been used comes from Wonogiri, Central Java, and then brought to the Mineral Processing Laboratory of the Department of Mining Engineering, Faculty of Mineral Technology, Universitas Pembangunan Nasional "Veteran" Yogyakarta for research. The galena mineral used in this study can be seen in Figure 1. The size of the galena mineral in the form of lumps is then reduced by using

Corresponding author:

ririazendymirahati@upnyk.ac.id

DOI: 10.31098/cset.v1i1.396

Research Synergy Foundation 
RSF Conference Series: Engineering and Technology

Vol. 1 (1), 355-362

Mineral Preparation Using Rod Mill for Mineral Galena Characterization

Riria Zendy Mirahati, Yasmina Amalia, Mochamad Juliyanto, Lintang Larasati Adi Putri

a hammer to reduce the grain size, which can be seen in Figure 2 . This is so that the galena mineral can enter the jaw crusher. The reduced sample is then weighed, the weighing process can be seen in Figure 3.

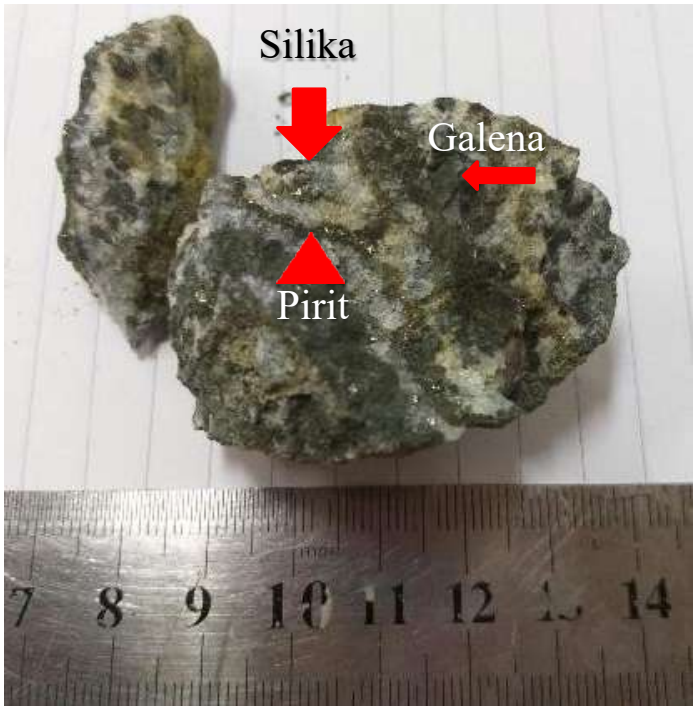

Figure 1. Mineral Galena

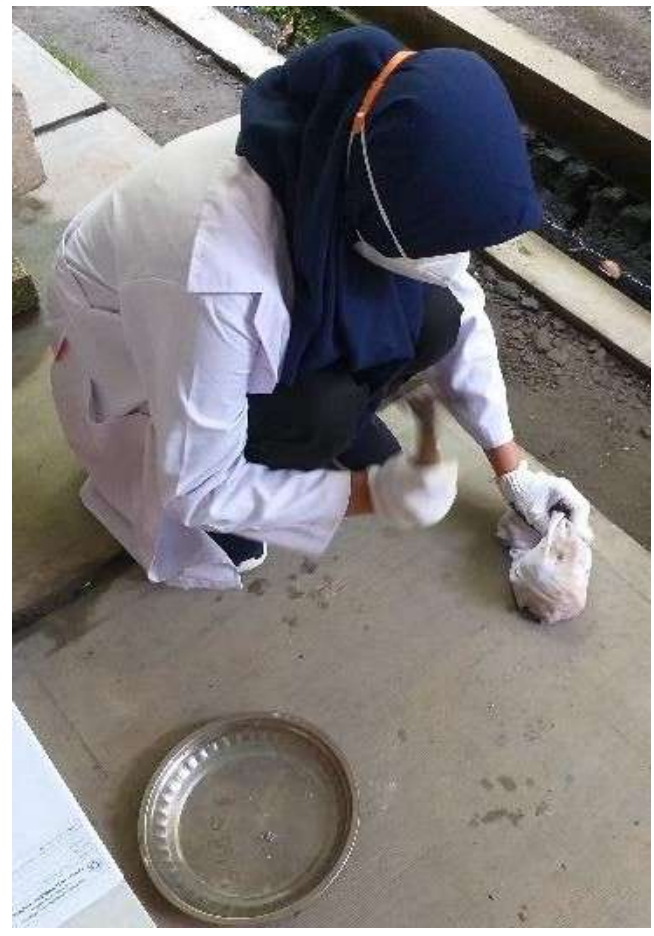

Figure 2. The process of reducing mineral grain size manually 


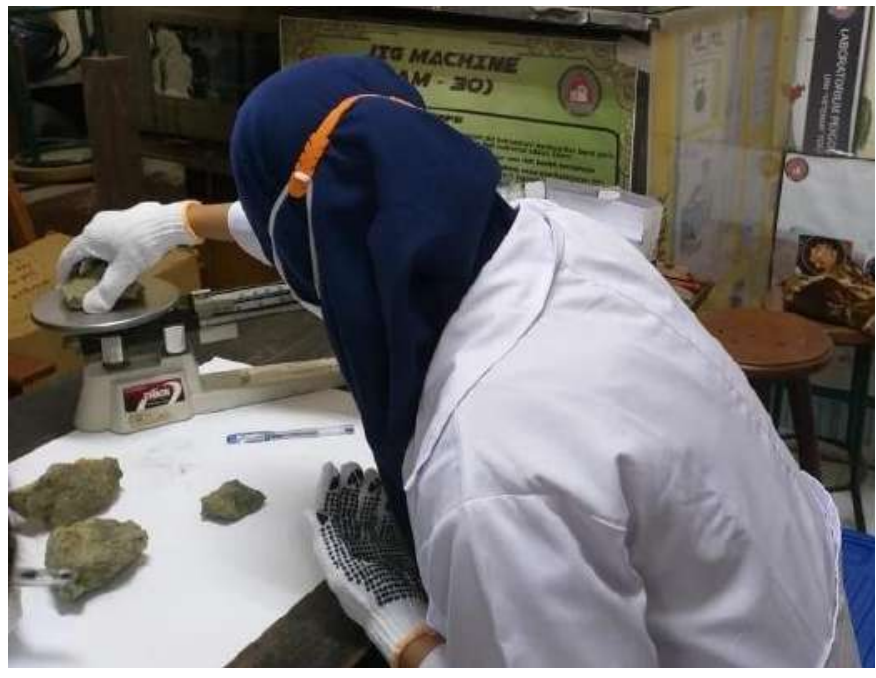

Figure 3. Galena sample weighing

Minerals that have been reduced manually are then further reduced to grain size, the grain size reduction process is carried out twice (primary and secondary). The process of reducing grain size in the first stage (primary) using a jaw crusher, can be seen in Figure 4. The process of reducing grain size using a jaw crusher is known as crushing. The results of the grain size reduction process using a jaw crusher are then carried out with a grain size grouping process, which can be seen in Figure 4. The grain size grouping process using a hanging sieve or siever can be seen in Figure 5. The sieves or sieves used are 48,65, 100, 150, 200 mesh. The purpose is to group grain sizes, so that the process of reducing the grain size in the second stage (secondary) is not too fine. The grain size that is too fine results in the formation of lumps at the concentration stage, so that the recovery will be less.

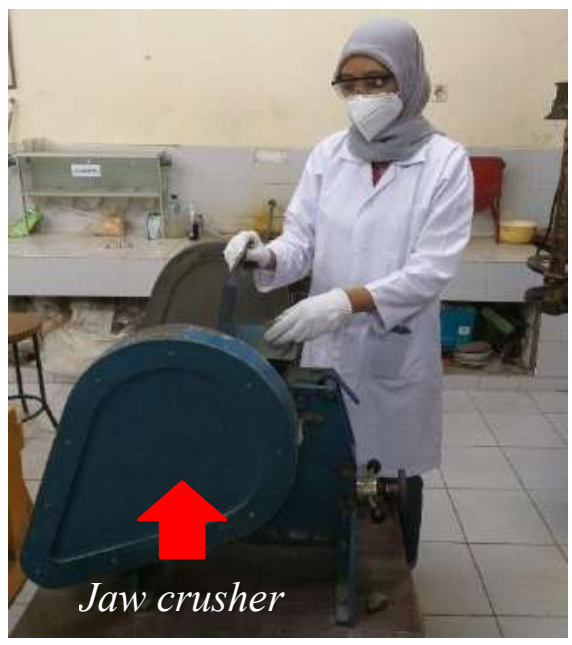

Figure 4. The process of reducing grain size using a jaw crusher 


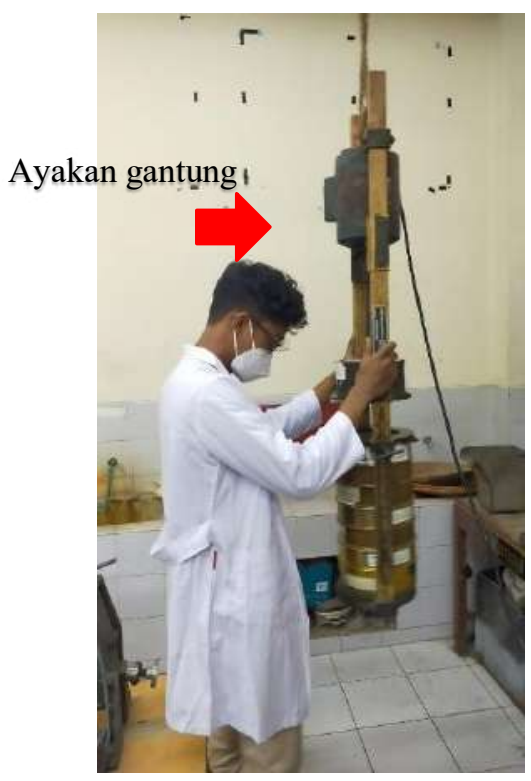

Figure 5. The process of grouping grains using a hanging sieve

The secondary stage process of reducing the grain size using a rod mill. Rod mill uses steel rods to grind the mineral galena into smaller sizes. The feed that enters the rod mill comes from the results of the jaw crusher which has been carried out in the sieving stage. The process of reducing grain size in the second stage is commonly known as grinding. The grinding process using a rod mill can be seen in Figure 6. The process that occurs in the rod mill is that steel rods hit the mineral galena so that there is friction and collisions between the steel rods with minerals and minerals with minerals when the mill rotates. The collision between steel rods with minerals and minerals with minerals causes large grain sizes to become smaller. The factors that influence the success of the grain size reduction process are the number of steel bars, the length of time the rod mill rotates, the hardness of minerals, and the material of the grinding media (grinder rods).

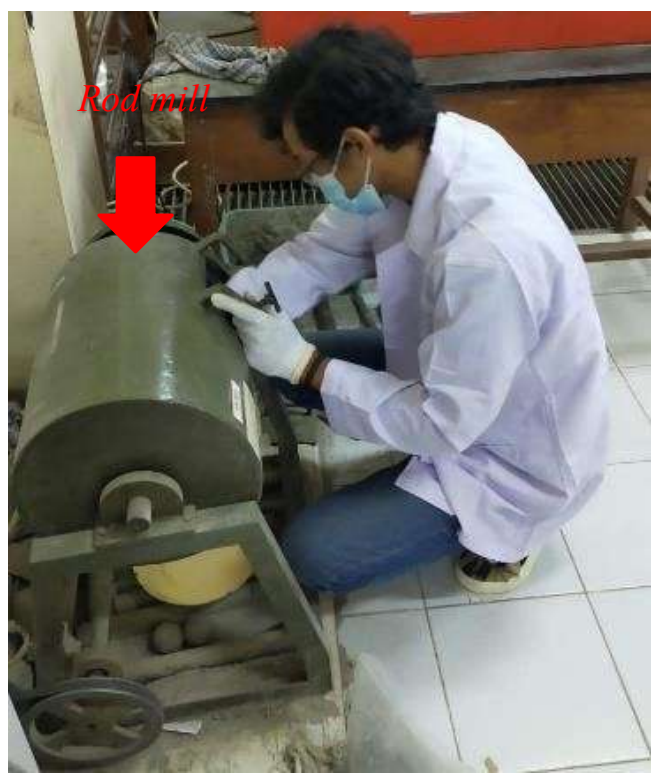

Figure 6. The process of reducing grain size using a rod mill 


\section{RESULTS AND DISCUSSION}

The length of time grinding 10 minutes. The crushed minerals are then sieved. The goal is to avoid a size that is too fine or smaller than 200 mesh. Data on the results of mineral grinding for 10 minutes after sieving can be seen in Table 1; Table 2; Figure 7 and Figure 8.

Table 1. Sieving Results after Going through the Grinding Stages

\begin{tabular}{|c|c|c|c|c|c|c|c|}
\hline \multirow{2}{*}{ Sample } & \multicolumn{6}{|c|}{ Weight recovery (grams) of each size in mesh } & \multirow{2}{*}{$\begin{array}{c}\text { Quantity } \\
\text { (gram) }\end{array}$} \\
\hline & +48 & $-48+65$ & $-65+100$ & $-100+150$ & $-150+200$ & -200 & \\
\hline I & 500 & 130 & 70 & 90 & 45 & 160 & 995 \\
\hline II & 605 & 35 & 50 & 65 & 40 & 185 & 980 \\
\hline III & 800 & 40 & 30 & 40 & 15 & 85 & 1010 \\
\hline IV & 770 & 35 & 25 & 35 & 25 & 85 & 975 \\
\hline $\mathrm{V}$ & 840 & 30 & 20 & 30 & 15 & 70 & 1005 \\
\hline VI & 860 & 20 & 20 & 20 & 20 & 50 & 990 \\
\hline VII & 750 & 55 & 40 & 40 & 30 & 90 & 1005 \\
\hline VIII & 800 & 80 & 60 & 70 & 40 & 100 & 1150 \\
\hline Quantity & 5925 & 425 & 315 & 390 & 230 & 825 & 8110 \\
\hline Prosentase (\%) & 73,06 & 5,24 & 3,88 & 4,81 & 2,84 & 10,17 & \\
\hline
\end{tabular}

Table 2. Sieving Results after Going through the Grinding Stages

\begin{tabular}{|c|c|c|c|c|c|c|c|}
\hline \multirow{2}{*}{ Sample } & \multicolumn{6}{|c|}{ Weight recovery (grams) of each size in mesh } & Quantity \\
\cline { 2 - 8 } & $\mathbf{+ 4 8}$ & $\mathbf{- 4 8 + 6 5}$ & $\mathbf{- 6 5 + 1 0 0}$ & $\mathbf{- 1 0 0 + 1 5 0}$ & $\mathbf{- 1 5 0 + 2 0 0}$ & $\begin{array}{c}\mathbf{2 0 0} \\
\text { (gram) }\end{array}$ \\
\hline I & 3390 & 170 & 115 & 100 & 80 & 180 & 4035 \\
\hline $\begin{array}{c}\text { Prosentase } \\
(\%)\end{array}$ & 84,01 & 4,21 & 2,85 & 2,48 & 1,98 & 4,46 & \\
\hline
\end{tabular}




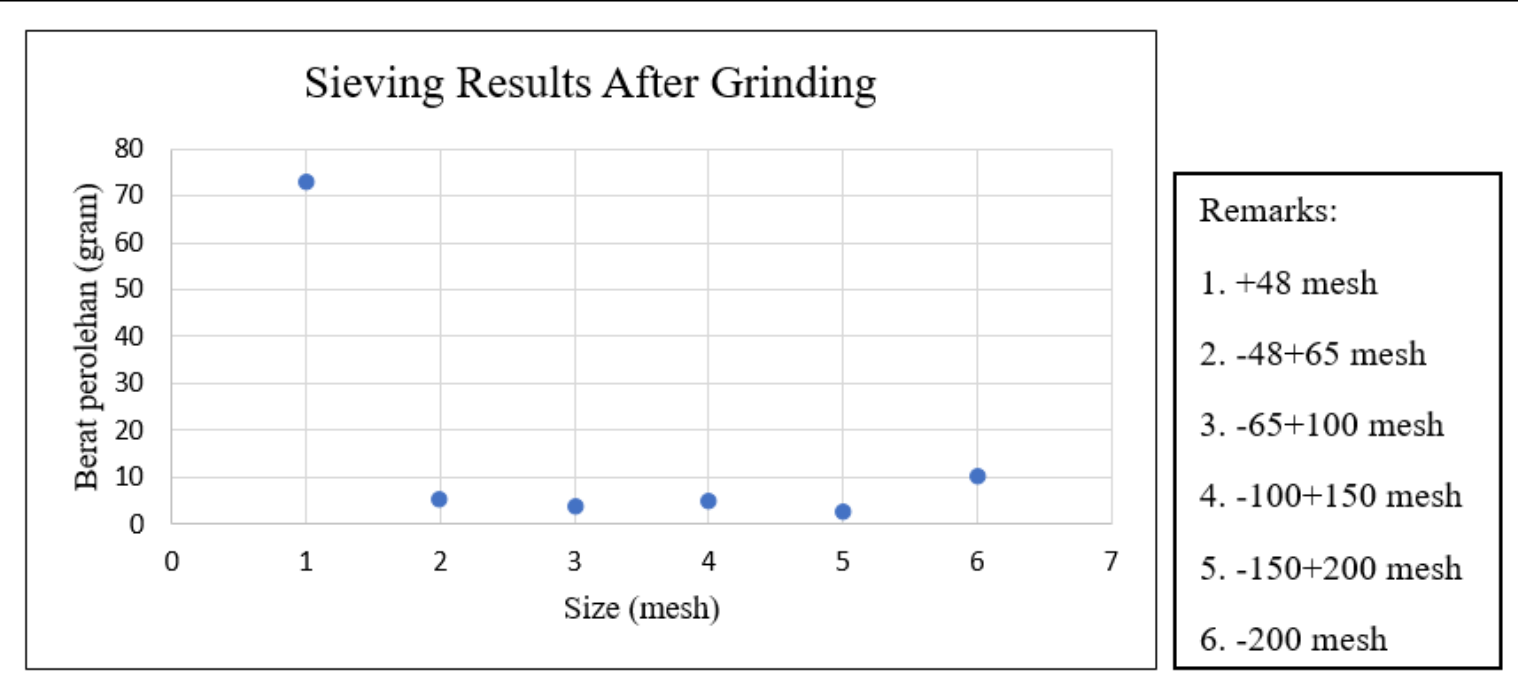

Figure 7. Sieving Results after Grinding Stages

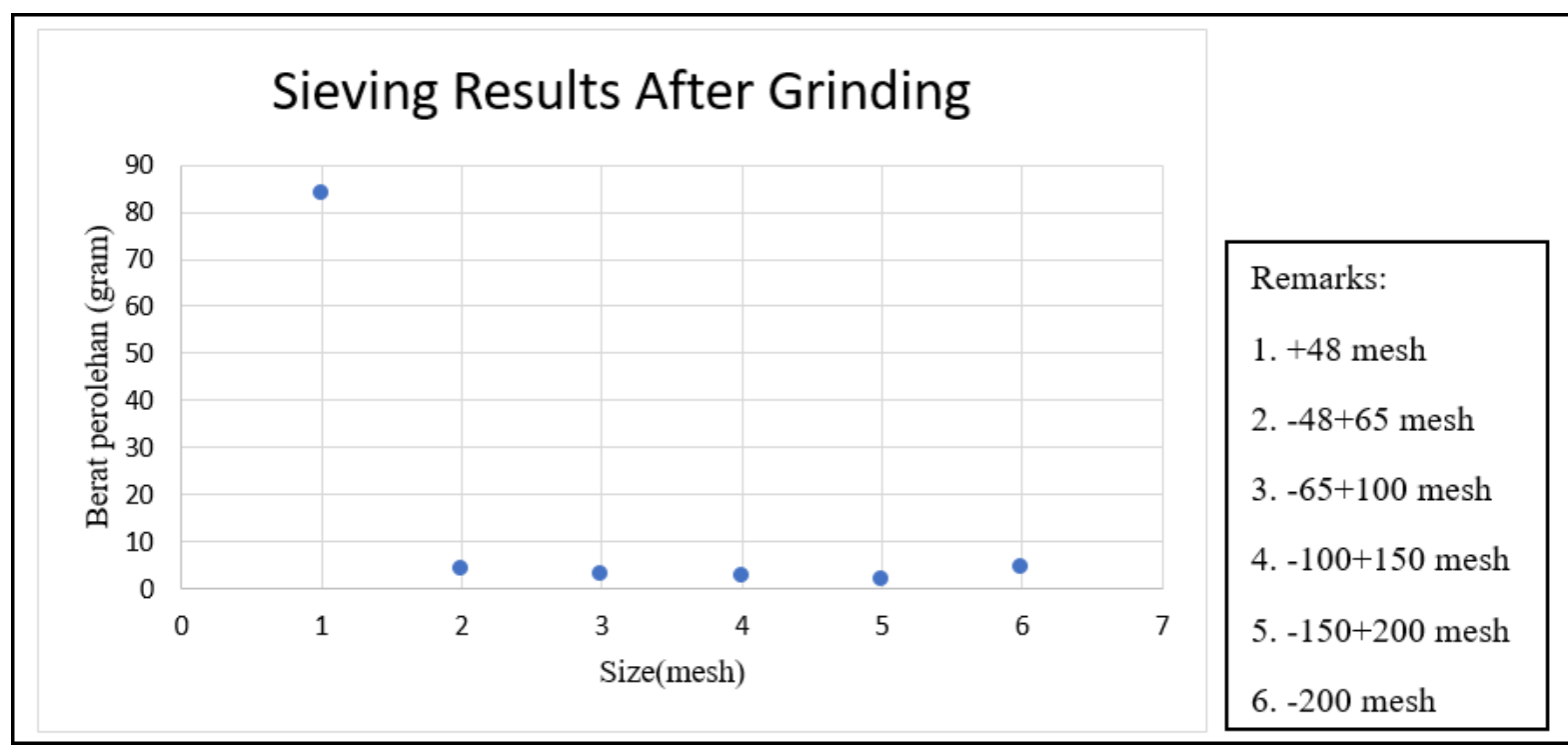

Figure 8. Sieving Results after Going through the Grinding Stages

Based on Figure 7 and Figure 8, the results of grinding galena minerals for 10 minutes after grouping the grain size using a seiver obtained +48 mesh of $73.06 \%$ and $84.01 \%$, respectively; $-48+65$ mesh by $5.24 \%$ and $4.21 \% ;-65+100$ mesh by $3.88 \%$ and $2.85 \% ;-100+150$ mesh of $4.81 \%$ and $2.48 \% ;-150+200$ mesh by $2.84 \%$ and $1.98 \% ;-200$ mesh of $10.17 \%$ and $4.46 \%$. The highest recovery is at grain sizes of more than 48 mesh, then at sizes smaller than 200 mesh. Grain size -48+65 mesh; -65+100 mesh; -100+150 mesh; and $-150+200$ mesh have relatively the same number. Galena mineral recovered in grain sizes of more than 48 mesh showed high recovery due to less grinding time. The grinding time is not long enough so that the grain size is still coarse, so additional grinding time is needed. 
In this study, the grain size of the mineral galena is required for mineral characterization before the concentration process in the form of flotation is carried out. Mineral characterization includes XRD (XRay Diffraction), XRF (X-Ray Fluorescence), SEM-EDS (Scanning Electron Microscope-Energy Dispersive X-Ray). XRD (X-Ray Diffraction) was tested to determine the compounds present in the ore, while XRF (XRay Fluorescence) was to determine the elements contained in it. SEM-EDS (Scanning Electron Microscope-Energy Dispersive X-Ray) was performed to analyze the topography or morphology of ore samples. The weight required for each test is 1 (one) gram of mineral at a size of - 200 mesh. This as a basis for grinding time for 10 minutes can already represent the need for galena minerals to be tested for mineral characterization.

\section{CONCLUSION}

The maximum recovery or grinding yield of galena is in the size of +48 mesh or greater than 48 mesh, which are $73.06 \%$ and $84.01 \%$, respectively. The galena mineral preparation process for the characterization of XRD (X-Ray Diffraction), XRF (X-Ray Diffraction), SEM-EDS (Scanning Electron Microscope-Energy Dispersive $\mathrm{X}$-Ray) minerals requires additional galena mineral grinding time, so that the grain size is not too large at +48 mesh. In addition, it is necessary to find the optimum time for the galena mineral grinding process so that there are not many minerals in the size of +48 mesh and -200 mesh.

\section{Acknowledgements}

Thank you for the Internal Research Grant of the Institute for Research and Community Service (LPPM) Universitas Pembangunan Nasional “Veterans” Yogyakarta 2021. Mining Engineering Mineral Processing Laboratory - Faculty of Mineral Technology, Universitas Pembangunan Nasional “Veterans” Yogyakarta

\section{REFERENCES}

Alaoui, LamiaeEl, AbdelilahDekayir. 2017. Theoretical study of the dissolution kinetics of

Dessy Amalia, Yunita Ramanda, Maryono. 2017. Extraction Of Lead From Galena Concentrates Using Fluosilicic Acid And Peroxide. Indonesian Mining Journal Vol. 20, No. 1.

Edy Sanwani, Riria Zendy Mirahati, Siti Khodijah Chaerun. 2015. Possible Role of the BiosurfactantProducing- and Fe-S-Oxidizing Bacterium in Silicate and Sulfide Bioflotation Processes. Advanced Materials Research Vol. 1130 (2015) pp 493-498. galena and cerussite in an abandoned mining area (Zaida mine, Morocco). E3S Web of Conferences 37, 01007 (2018).

Graeme P. Sheldon, N.W. Johnson. 2018. Galena Flotation Witb Metabisulpbite: Solutions to Problems from Xantbate Sulpboxy Ion Reactions. The AuslMM Bulletin and Proceedings, Vol 293, No 3.

Haldar, S.K. 2015. Galena exhibits an IR-absorption band that lies outside the spectral range of commercially available IR cameras with the highest resolution. Sciencedirect.

Harwan. 2018. Karakteristik Alterasi Dan Mineralisasi Bijih Besi Daerah Pakke Kecamatan Bontocani Kabupaten Bone Sulawesi Selatan. Program Pascasarjana Universitas Hasanuddin Gowa.

Irzal Nur. 2012. Geology, Geochemistry and Fluid Inclusion Study Of The Baturappe Epithermal SilverBase Metal Prospect, South Sulawesi, Indonesia. Program Pascasarjana Fakultas Teknik Program Studi Teknik Geologi Universitas Gadjah Mada Yogyakarta. 


\section{RSF Conference Series: Engineering and Technology}

Vol. 1 (1), 355-362

Mineral Preparation Using Rod Mill for Mineral Galena Characterization Riria Zendy Mirahati, Yasmina Amalia, Mochamad Juliyanto, Lintang Larasati Adi Putri

Jamaluddin, Emi Prasetyawati Umar. 2018. Identifikasi Kandungan Unsur Logam Batuan Menggunakan Metode XRF (X-RAY FLOURESCENCE) (Studi Kasus: Kabupaten Buton). Jurnal Geocelebes Vol. 2 No. 2.

Kant, Win, I Wayan Warmada, Arifudin Idrus, Lucas Donny Setijadji, KoichiroWatanabe. 2012. Ore Mineralogy and Mineral Chemistry Of Pyrite, Galena, And Sphalerite At Soripesa Prospect Area, Sumbawa Island, Indonesia. J. SE Asian Appl. Geol., Jan-Jun 2012, Vol. ～4(1), pp. 1-14.

Mei Yang, Wending Xiao, Xiang Yang, Patrick Zhang. 2016. Processing MineralogyStudy on Lead and Zinc Oxide Ore in Sichuan. Academic Editor: Corby G. Anderson.

Mejía, E.R, J. D. Ospina, M. A. Márquez, A. L. Morales. 2012. Bioleaching of Galena (PbS). www. Intechopen.com.

Natarajan. K.A. 2006. Biotechnology for Metal Extraction, Mineral Beneficiation and Environmental Control. Proceedings of the International Seminar on Mineral Processing Technology - 2006, Chennai, India. pp. 68 - 81.

Ngurah Ardha. 2011. De-Zincing of Lead-Copper Sulphideminerals Flotation. Indonesian Mining Journal Vol.14. No.1.

Nnanwube, Ikechukwu A, Okechukwu D. Onukwuli. 2018. Hydrometallurgical Processing of a Nigerian. Journal of Minerals and Materials Characterization and Engineering, 2018, 6, 271293.

Nooshabadi, Alireza Javadi, Kota Hanumantha Rao. 2015. Effect of GrindingEnvironment on Galena Flotation. The Open Mineral Processing Journal, 2015, 8,1-6.

Nora Idiawati, Annisa Triantie, Nelly Wahyuni. 2013. Pemisahan Timbal (Pb) Dalam Galena Dengan Metode Flotasi Menggunakan Deterjen. Positron, Vol. III, No. 1.

Raza, M.A., M.A. Bhatti, S. Nasir, F. Bashir, Z. Mahmood, K.R. Kazmi, I. Hafeez.2019. Study $\quad$ On Low-Grade Galena-Barite Ore Beneficiation in Khuzdar, Balochistan, Pakistan. Mining of Mineral Deposits.

Soroush Rahmati Shahreza, Seyed Ziaodin Shafaei, Mohammad Noaparast, MehdiNasiri Sarvi. 2015. Optimization of Galena Flotation Process of Irankouh Complex Ore using A Statistical Design of Experiments. Current World Environment Vol. 10 (Special Issue 1).

Vasanthakumar, Balasubramanian, Honnavar Ravishankar, Sankaran Subramanian. 2012. A Novel Property of DNA - As a Bioflotation Reagent in Mineral Processing. Published: July 2, 2012. https://doi.org/10.1371/journal.

Yildirim, Demet Kiran, Attila Kilinc, Fikret Suner, Mustafa Kumral, Gokce K. Ustunisik, Murat Budakoglu. 2013. Origin of galena and sphalerite mineralization in theKoru Volcanics, Biga Peninsula, Turkey: insights fromMELTS modelling and SUPCRT calculations. May 2013International Geology Review 55(7).

Yongjie $\mathrm{Bu}$, Yuehua $\mathrm{Hu}$, Wei Sun, Zhiyong Gao, Runqing Liu. 2018. Fundamental Flotation Behaviors of Chalcopyrite andGalena Using O-Isopropyl-N-Ethyl Thionocarbamate As A Collector. www.mdpi.com. 